\title{
Defining diagnostic tissue in the era of personalized medicine
}

\author{
Carol C. Cheung MD PhD, Bella R. Martin MHA LLB, Sylvia L. Asa MD PhD
}

$\mathrm{H}$ uman tissue is excised for either medical care or research. Demand for excised human tissue is increasing because of the realization of personalized medicine, which relies on excised human tissue to develop innovative tests for application in patient care. However, because excised human tissue is a limited, nonrenewable resource, increasing demand has stressed current institutional infrastructures.

Excised human tissue consists of 2 classes diagnostic and research — each with distinct rules governing collection, retention and use. Because of a dearth of published literature on the fundamental distinction between diagnostic and research tissue, there is confusion among institutions, physicians, researchers and patients regarding access to excised human tissue. Any meaningful future discourse and decisions about responsible access to excised human tissue therefore require definitional clarity surrounding this distinction. Here we present a conceptual framework based on current medical, legal and ethical doctrines to clearly define diagnostic tissue and to determine who is responsible for it by examining who ultimately "owns" it, including the application of informed consent to the question of tissue ownership. Although we refer to Ontario legislation when citing specific provisions, other Canadian jurisdictions have similar provisions. ${ }^{1-5}$

\section{Defining diagnostic tissue}

Diagnostic tissue is all tissue obtained during a medical procedure for patient care that, in accordance with applicable legislation, ${ }^{6}$ must be sent to the laboratory or department of pathology for documentation of what was excised; measurements and description, including any abnormalities; and an interpretation (or diagnosis) of health or disease status. Examination by direct visual and tactile observation is always performed and, where indicated, medically appropriate portions are sampled for further evaluation by histologic, molecular and ultrastructural examination or other methods.

What constitutes diagnostic tissue is addressed in law. ${ }^{6}$ As such, diagnostic tissue includes that which is wet unfixed or fixed, frozen, formalinfixed paraffin-embedded and derivatives of these forms, including sections mounted on glass slides cut from formalin-fixed paraffin-embedded blocks, as well as extracted materials or information (e.g., DNA, RNA, protein).

Diagnostic tissue that has undergone gross examination and is not specifically sampled and processed for further study is excess diagnostic tissue, which is retained short term (i.e., weeks) and then discarded as medical or biological waste. All sampled and processed tissue is retained as archived diagnostic tissue for a minimum of 20 years in archives of the department of pathology in accordance with statutory and laboratory licensing and accreditation requirements.? It, too, is eventually discarded as medical or biological waste.

In contrast, research tissue is tissue that is specifically available for research. It is stored in a research biobank, not in clinical archives of a pathology department. Research tissue may be obtained directly through biopsy or excision from an individual with appropriate consent, or, less commonly, indirectly through salvaging excess diagnostic tissue or archived diagnostic tissue after their respective mandatory retention periods have elapsed (Figure 1). This must be distinguished from situations in which excess diagnostic tissue or archived diagnostic tissue,

\section{- Ker points}

- Diagnostic tissue must be distinguished from research tissue because the uses of these tissues are governed by different rules.

- Diagnostic tissue, as a component of the patient record, is owned by the institution.

- The requirement for informed consent with respect to use of diagnostic tissue is contextual and relates to privacy rights, not property rights.

- Departments of pathology, as institutional stewards, must bear primary responsibility for decisions regarding diagnostic tissue. 
while still within their mandatory retention periods, may be used for research.

\section{Distinguishing diagnostic from research tissue}

There is a misconception that tissue excised during a medical procedure may be considered both diagnostic tissue and research tissue. This may be because, although the same piece of tissue cannot simultaneously be both, research tissue may sometimes be excised from an individual concurrently with diagnostic tissue (i.e., removal of additional tissue during a procedure beyond what would have otherwise been removed had the research study not existed). Tissue should be characterized by its reason for removal ${ }^{6}$ at the time of excision, and not by its ultimate use. The "but for" ${ }^{8}$ concept used to assess causation in tort law (i.e., but for a specific act, the resultant damage would not have occurred), may present a useful construct to distinguish diagnostic tissue from research tissue. If the answer to the question, "But for study X, would this tissue (or this amount of tissue) have been excised from this individual?" is "no," then that particular excised tissue (or the portion beyond which would not have been obtained but for the study) can be classified as research tissue from the moment it is excised. If, however, the answer is "yes," "maybe" or "partially" — anything other than an unequivocal "no" - then the excised tissue should be considered diagnostic tissue. And although it is true that, in some circumstances, diagnostic tissue may be used for research, that does not, in and of itself, make it research tissue. This distinction is important because the rules governing acquisition, handling, storage and use of diagnostic and research tissue are different. As

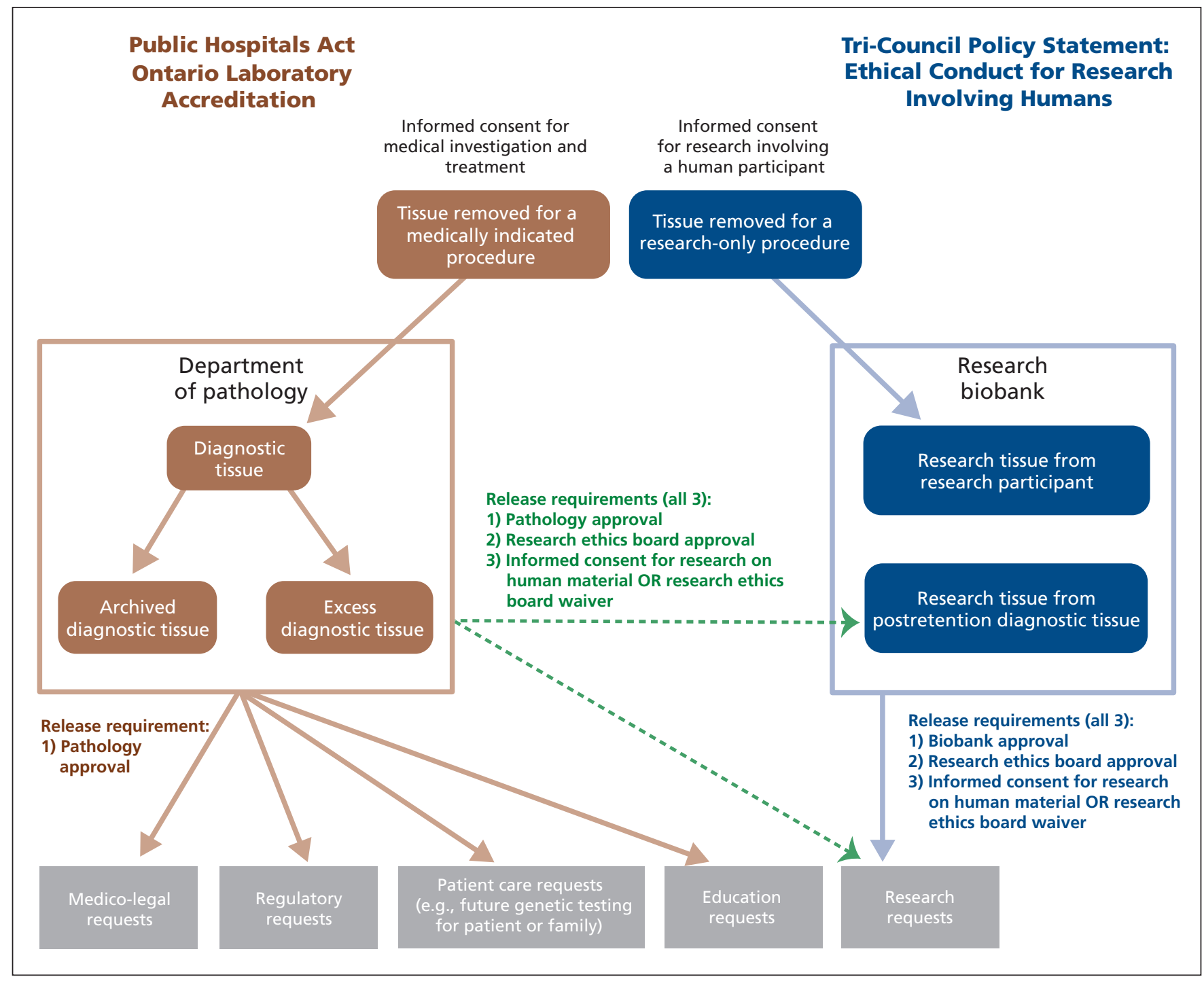

Figure 1: Schematic depiction of the relation between diagnostic and research tissue. 
such, the fundamental question of who is authorized to make decisions regarding diagnostic tissue must be addressed.

\section{Ownership issues involving diagnostic tissue}

Those seeking to deny institutional ownership of excised human tissue have argued that it is the patient who holds such rights and can dictate how and where excised human tissue is to be stored, accessed and used. It is unquestionably true that patients own their tissue before it is excised. However, a persuasive argument can be made that this is not so after excision, especially where the tissue ends up in a materially different form (e.g., slides, paraffin-embedded blocks). Although this issue has never been squarely dealt with by a Canadian court, we will examine it through the definitional lens of tissue as a component of the medical record and also by reference to several cases in the United States that have held in favour of institutional ownership.

\section{Tissue as a component of the medical record}

Ownership of diagnostic tissue is alluded to in the context of the medical record. By law, hospitals are required to retain "slides made for microscopic examination from tissue removed from a patient or an outpatient on which a report has been made" as part of the patient's medical record. Although neither wet tissue nor formalin-fixed paraffin-embedded tissue is specifically referred to in Regulation 965 under the Public Hospitals Act, it is difficult to conceive of any principled reason why the forms of tissue from which the slides were derived would be treated differently than the slides themselves. This is especially true of diagnostic paraffin blocks because the tissue sections mounted on glass slides are generated for the sole purpose of enabling direct visualization of the tissue within the block.

In McInerney v. MacDonald, ${ }^{9}$ the Supreme Court of Canada acknowledged that a "patient is entitled to reasonable access to examine and copy the records" but was clear that the party responsible for compiling the tangible medical record is its rightful owner. The Canadian Medical Association has further stipulated that the owner of the record has authority to use the contents for secondary purposes including epidemiologic studies, research, education, remuneration for services rendered and quality assurance. ${ }^{10,11}$ By virtue of it being part of the medical record, diagnostic tissue is therefore owned by the institution or hospital.
At best, the patient is entitled to "reasonable access to examine and copy the records," but an important challenge is that, unlike paper or electronic records, tissue cannot be duplicated without destroying a portion of the original record.

\section{Excised tissue: Donation or loan?}

A bailment (loan) arises where possession - not ownership - of property is transferred from a "bailor" to a "bailee." With a gift (donation), however, a transfer of ownership does occur. Whereas there is no Canadian jurisprudence related to ownership of tissue outside of the context of medical records, several American courts have held that with respect to tissues submitted for clinical or research purposes, a transfer of ownership has occurred and, thus, must be considered a donation rather than a loan. ${ }^{12}$

In Moore v. Regents of the University of California,${ }^{13}$ the seminal case on ownership rights in excised human tissue, John Moore's physician, without obtaining informed consent, used tissues extracted during repeated medical visits to develop and patent a cell line. Moore sued the university, asserting ownership of his cells and derivative products. The Supreme Court of California held that "once the cells have been excised from a patient's body, he loses control over them and hence, loses any proprietary interest." ${ }^{14}$

In Greenberg v. Miami Children's Hospital Research, ${ }^{15}$ relatives of individuals with Canavan disease donated tissue to researchers to develop a publicly available prenatal screening test. When the institution subsequently patented and commercialized the new test instead, the donors filed suit citing a lack of informed consent. The court held that a patient's property rights to tissue extinguished at the time of donation. ${ }^{16}$

In Washington University v. Catalona, ${ }^{17} \mathrm{Dr}$. William Catalona of Washington University, with informed consent, collected thousands of tissue samples from patients for his research. Washington University refused Catalona's attempts to take the samples with him to a new institution, although Catalona had obtained written authorization for the transfer from numerous patients. Washington University asserted ownership of the tissue and sued for a declaratory judgment to that effect. The patients then claimed a proprietary interest in the samples to support transfer of the tissue to Catalona's new institution. Both a US district court and a court of appeals held in Washington University's favour, claiming patients had no ownership rights in the tissues, which were considered valid gifts. ${ }^{17}$ Furthermore, Washington University could use the tissue for whatever research or commercialization purposes it desired. A patient's rights were 
limited to the contractual terms of the informed consent. The court ruled that patients could prevent the continued use of already collected samples by Washington University, but they could not force Washington University to transfer the samples to another institution.

In summary, to date, American courts "consistently have rejected the idea that patients are the owners of their excised tissues or retain any property rights." ${ }^{\prime 18}$ An exception to this principle could arise in situations in which steps to assert ownership were taken proactively, or in which consent forms or other documentation explicitly preserved such ownership rights. That is to say, unless the patient realistically expects the tissue to be returned to him or her, ownership is considered relinquished at the time of excision.

\section{Privacy or property: the role of informed consent}

Some have suggested that the requirement for patient consent before the use of excised human tissue for research means patients do have ownership rights, or why else would that consent be necessary? The short answer is that consent is only sometimes required, and, arguably, the reason for this requirement has everything to do with privacy rights and nothing to do with ownership or property rights.

We will briefly review 2 settings in which informed consent is required: medical investigation and treatment, and research. ${ }^{19,20}$

The importance of informed consent for medical investigation and treatment has been clearly established by the Supreme Court of Canada in Hopp v. Lepp ${ }^{21}$ and Riebl v. Hughes. ${ }^{22}$ Absence of informed consent in such situations can give rise to claims of negligence, battery or both, with resultant legal and regulatory consequences. For this reason, practitioners must obtain informed consent from patients undergoing any medical treatment, including the excision of diagnostic tissue during a medically indicated procedure.

The requirement for informed consent in research is aimed at protecting human participants by ensuring they have the right to refuse or withdraw their participation at any time..$^{20}$ Its roots can be traced back to landmark documents such as the Nuremberg Code, ${ }^{23}$ the Declaration of Helsinki ${ }^{24}$ and the Belmont Report, ${ }^{25}$ all of which evolved in response to horrific episodes of medical experimentation perpetrated on unwilling or unwitting human beings. Two of the most infamous examples are the experiments performed by Nazi physicians on unwilling prisoners during World War II and the Tuskegee
Syphilis Study performed by physicians and researchers on unsuspecting American patients. ${ }^{26,27}$ The Declaration of Helsinki, ${ }^{24}$ espousing principles on which many subsequent ethical guidelines are based (including portions of Canada's Tri-Council Policy Statement ${ }^{28}$ ), states that informed consent is required for any research involving "human subjects" and includes research on "identifiable" human material or data. However, if human material or data cannot be linked to a particular individual, informed consent is not required. ${ }^{19,26,29}$ Thus, informed consent for research on "human subjects" applies to both the acquisition of "identifiable" research tissue (i.e., by direct excision from a research participant or by salvaging excess or archived diagnostic tissue after retention and before disposal), and to use of "identifiable" diagnostic and research tissue for research.

Therefore, the requirement for informed consent is not an acknowledgement of patient ownership rights to excised tissue. Rather, it is recognition of a patient's right to autonomy over his or her intact physical body and the right to privacy and confidentiality over his or her identifiable health (including genetic) information. ${ }^{29}$ This principle can be illustrated by examining the situation in which informed consent for secondary use of biological materials for research may be waived by an institutional research ethics board if it believes that samples can be anonymized such that the "risk of re-identification of individuals ... is low." ${ }^{28}$ If informed consent were intended to recognize property rather than privacy rights, then such anonymization of samples for use without informed consent would amount to theft of property. Interestingly, in Moore v. Regents of the University of California, Moore's claim for "conversion" (a common law tort defined as the voluntary act by one person inconsistent with the ownership rights of another) was struck down by the Supreme Court of California. ${ }^{13}$

To summarize, the requirement for informed consent with respect to acquisition and use of excised human tissue is contextual and relates to autonomy and privacy rights, not property rights. In the medical practice setting, informed consent is required to excise tissue as part of a medically indicated intervention. That tissue is considered diagnostic tissue and comes under the control of the laboratory of the institution where the intervention was performed. Rules for the subsequent handling, examination, retention and disposition of diagnostic tissue are governed by both statutory requirements (i.e., medical records retention $)^{6}$ and regulatory requirements of laboratory licensing bodies. ${ }^{7}$ In the research setting, informed consent is required to excise any tissue 
that is not part of a medically indicated intervention and to use any "identifiable" diagnostic tissue for research. Furthermore, the owner or legal steward of that diagnostic tissue must agree to its release. Informed consent for using tissue for research may be waived if, in the opinion of the institutional research ethics board, the risk of reidentification of individuals is low.

\section{Stewardship of diagnostic tissue}

So, who is accountable for decisions regarding diagnostic tissue? Under the current North American medical, legal and ethical framework, it is institutions or their designated stewards in practice, pathology departments - that must be responsible for striking the right balance between the duty to retain diagnostic tissue in accordance with statutory and regulatory requirements and the ever-increasing demand for what still represents the richest source of clinically annotated human tissue in this era of personalized medicine. ${ }^{30,31} \mathrm{We}$ will address in subsequent papers what considerations should be taken into account when making those decisions.

\section{Conclusion}

We have defined diagnostic tissue and introduced the "but for" test to distinguish diagnostic tissue from research tissue. We have shown that diagnostic tissue, as a component of the medical record, is owned by the institution. We reason, with support from American jurisprudence, that once excised, both possession and ownership of tissue are transferred to the institution. We contend that the doctrine of informed consent does not confer property rights and, thus, should not be used to deny institutional control of diagnostic tissue. Our analysis also shows that the responsibility for decisions regarding diagnostic tissue is institutional and lies with the designated institutional stewards of diagnostic tissue. Finally, while writing this article, we realized that given the complexity of issues relating to excised human tissue, we would be unable to adequately address all aspects of this broad topic in a single article. In future papers, we will address issues that arise when new or unanticipated research findings can affect the participant, and the intellectual property ramifications implicit in the secondary use of diagnostic tissue.

\section{References}

1. Hospitals Act, RSM 1987, c. H120.

2. Hospitals Act, RSPEI 1988, c H-10.1.

3. Hospitals Act, RS 1989, c. 208.

4. Hospital Act, SNB 1992, c H-6.1.

5. Hospitals Act, RSA 2000, c. H12.

6. Public Hospitals Act, RRO 1990, Regulation 965, ss. 20(2)3, 31(1), 31(2).

7. Ontario Laboratory Accreditation requirements. In: Post-analytical process. Toronto (ON): Quality Management Program Laboratory Services; 2011.

8. Weinrib E. Tort law: cases and materials. 3rd ed. Toronto (ON): Emond Montgomery Publications; 2008. p. 792.

9. McInerney v. MacDonald [1992] 2 SCR 138

10. Canadian Medical Association. The medical record: confidentiality, access and disclosure (update 2000). Ottawa (ON): The Association; 2000.

11. Canadian Medical Association. Principles for the protection of patients' personal health information. Ottawa $(\mathrm{ON})$ : The Association; 2011.

12. Allen MJ, Powers ML, Gronowski KS, et al. Human tissue ownership and use in research: what laboratorians and researchers should know. Clin Chem 2010;56:1675-82.

13. Moore v. Regents of University of California, 51 Cal. 3d 120, 132-133, 793 P.2d 479, 486, 271 Cal. Rptr. 1990;146:153.

14. Mossman MJ, Flanagan W. Property law: cases and commentary. 2nd ed. Toronto (ON): Emond Montgomery Publications; 2004.

15. Greenberg v. Miami Children's Hospital Research Institute, 264 F. Supp. 2d 1064 (S.D. Fla. 2003).

16. Hakimian R, Korn D. Ownership and use of tissue specimens for research. JAMA 2004;292:2500-5.

17. Washington University v. Catalona, 490 F.3d 667 (8th Cir. 2007).

18. Dry S. Who owns diagnostic tissue blocks? Lab Med 2009;40: 69-73.

19. del Carmen MG, Joffe S. Informed consent for medical treatment and research: a review. Oncologist 2005;10:636-41.

20. Elger BS, Caplan AL. Consent and anonymization in research involving biobanks: Differing terms and norms present serious barriers to an international framework. EMBO Rep 2006;7:661-6.

21. Hopp v. Lepp, [1980] 2 S.C.R. 192.

22. Reibl v. Hughes, [1980] 2 S.C.R. 880.

23. US National Institutes of Health. Nuremberg Code. Available: http://history.nih.gov/research/downloads/nuremberg.pdf (accessed 2012 June 28).

24. World Medical Association. The World Medical Association Declaration of Helsinki: ethical principles for medical research involving human subjects. Ferney-Voltaire (France): The Association; 2008.

25. US Department of Health \& Human Services. The Belmont Report. Available: www.hhs.gov/ohrp/humansubjects/guidance /belmont.html (accessed 2012 June 28).

26. Bertholf RL. Protecting human research subjects. Ann Clin Lab Sci 2001;31:119-27.

27. Harnett JD, Neuman R. Research ethics for clinical researchers. Methods Mol Biol 2009;473:285-97.

28. Tri-Council Policy Statement: ethical conduct for research involving humans. Ottawa (ON): Canadian Institutes of Health Research, Natural Sciences and Engineering Research Council of Canada, and Social Sciences and Humanities Research Council of Canada; 2010.

29. Caulfield TA, Ries NM. Consent, privacy and confidentiality in longitudinal, population health research: the Canadian legal context. Health Law J 2004;(Suppl): 1.

30. Bathe OF, McGuire AL. The ethical use of existing samples for genome research. Genet Med 2009;11:712-5.

31. Giannini C, Oelkers MM, Edwards WD, et al. Maintaining clinical tissue archives and supporting human research: challenges and solutions. Arch Pathol Lab Med 2011;135:347-53.

Affiliations: From the Departments of Pathology (Cheung, Asa) and Legal Affairs (Martin), University Health Network, Toronto, Ont.

Contributors: All authors contributed to the conception and design of the manuscript, which Carol Cheung drafted. All authors revised the manuscript and approved the version submitted for publication. 